\title{
«Диалогичность» как семантическая и семиотическая динамика литературного текста
}

\author{
Семиотика литературы в контексте лингвистики \\ и языковой коммуникации
}

\begin{abstract}
КАТАЛИН КРОО
KRoÓ Katalin, ELTE Orosz Nyelvi és Irodalmi Tanszék, H-1088 Budapest, Múzeum krt. 4/D. E-mail: krookatalin@freemail.hu
\end{abstract}

(Received: 15 March 2016; accepted: 25 May 2016)

\begin{abstract}
The article entitled "Dialogism as the Semantic and Semiotic Dynamic of the Literary Text (Literary Semiotics in the Context of Linguistics and Linguistic Communication)" investigates the question of the possibility and importance attached to the definiton and differentiation of the semantic and semiotic aspects and modes of literary text-formulation. This question is raised through the examination and by putting into correlation the semantic and semiotic text-developmental processes in terms of the dynamic nature of the literary work, revealing itself in semantic and semiotic dialogues. To functionally define this kind of dialogical semantic and semiotic communication, the resarch works out a theoretical framework for the interpretation with the starting point being Benveniste's conceptualisation of the semiotic and semantic. The article tries to reconstruct a broader context for the Benvenistian terms and concepts, on the one hand, involving parallel reading of his The Semiology of Language and Voloshinov/Bakhtin's Marxism and the Philosophy of Language, and, on the other, relying on the extension of the Bakhtinian interpretative contexts for the concept of dialogue. In this process, the opposition of the semiotic and semantic is eliminated, being transformed into the poetological principle of intersemiotic meaning-generation in the literary text. To convert theory into practice, a brief close reading sample is offered from Lermontov's novel A Hero of Our Time.

Keywords: dialogism, semantic, semiotic, text-dynamic, Benveniste, Bakhtin, A Hero of our Time
\end{abstract}

В настоящей работе подвергается рассмотрению понятие семантической и семиотической динамики литературного текста и взаимосвязь этих двух текстопорождающих сил. ${ }^{1}$ Ставится вопрос об адекватности концептуального определения и описания процессов семиотизации в литературном тексте с точки зрения художественной семантики, и наоборот, о возможности или

\footnotetext{
${ }^{1}$ Проблематика соотношения семантической и семиотической динамики в литературном тексте впервые была выдвинута нами в докладе «,Диалогичность“ как семантическая и семиотическая динамика литературного текста» на международной конференции «Bakhtin 120. After Cognition: Word, Act and Culture as Event of Being. International Conference in Honor of the 120th Anniversary of Mikhail Bakhtin's Birth» (28-29 May 2015, University of Pannonia, Veszprém, Hungary). Настоящая статья является расширенным вариантом прозвучавшего на указанном симпозиуме доклада.
} 
необходимости исследовать процессуально развивающийся и глобальный поэтический замысел литературного произведения с перспектив динамики семиотизации текста. Выдвинутые дилеммы мы будем трактовать в контексте научного наследия творчества М. Бахтина и бахтинского круга ученых.

Постановка вопроса о различении семиотической и семантической динамики в литературном произведении неотрывна от теоретических и методологических поисков в области научного определения дисциплинарных идентитетов семантики и семиотики и их связи. Теории семиотики с любым своим специфическим уклоном определения дисциплины должны учитывать разные возможные контексты сфер семантизации - см., например, установку на проблематику знаковости как таковой и на описание семиотических систем (любая теория знака), или на феноменологическую перцепцию знака (связь семиотики как с философией, так и когнитивными науками), или на обмен информацией в процессах коммуникации (связь семиотики с теорией коммуникации), или на интегрированность знаковости в культурных контекстах (связь семиотики с теориями культуры) и т. д.

Эмиль Бенвенист в известном своем утверждении четко противопоставляет семиотическое и семантическое лингвистическое восприятие языка: «Семиотическое (знак) должно быть узнано, семантическое (речь) должно быть понято» (Бенвенист 1974: 88; cp. BENVENISTE 1969b: 134). ${ }^{2}$ Процитированную мысль ученого уже не один исследователь комментировал в контексте научного наследия Бахтина и его интеллектуального круга (ИвАнов 1973, ИвАнов 2001). ${ }^{3}$ В этом отношении необходимо вспомнить следующее оформление релевантной идеи: «Таким образом, конститутивным моментом для языковой формы как для знака является вовсе не ее сигнальная себетождественность, а ее специфическая изменчивость, и для понимания языковой формы конститутивным моментом является не узнание „того же самого“, а понимание в собственном смысле слова, т. е. ориентация в данном контексте и в данной ситуации, ориентация в становлении, а не ,ориентация“ в каком-то неподвижном пребывании» (Волошинов/БАХТин 2000: 405). В идее «ориентации в становлении, а не в... неподвижном пребывании» противопоставляются не только аспект устойчивости значения - статика - и генезис смысла как динамика. Понимание становления определяется как фактор лежащего «в основе ответа, т. е. речевого взаимодействия». Речевое взаимодействие предполагает близость понимания к ответу («Между пониманием и ответом нельзя провести резкой границы»), так как «всякое понимание отвечает» в скобках.

2 Далее будем ссылаться только на русский перевод данной статьи через номера страниц

${ }^{3}$ Как Петер Гржибек формулирует: «В 1970 году Вяч. Вс. Иванов назвал М. М. Бахтина единственным автором работ, напечатанных под фамилиями Бахтина, В. Н. Волошинова и П. Н. Медведева, и тем самым открыл дискуссию об авторстве, продолжающуюся и сегодня» (ГржиьЕк 1995: 240 и далее). Детально об истории исследования данного вопроса и аргументацию см. АлПАтов 2005, особенно: 94-118. Мы ссылаемся на работу «Марксизм и философия языка» как Волошинов/БАХТин 2000. 
таким путем, что «переводит понимаемое в новый контекст, в возможный контекст ответа» (Волошинов/БАХтин 2000: 405). Итак, «ориентация в становлении» у Волошинова/Бахтина определяется общим свойством диалогического действия высказывания, создающегося переводом изначального контекста в ответный контекст высказывания. Проблема неотделимой от речи (высказывания) семантики (Бенвенист), следовательно, в осмыслении Волошинова/Бахтина толкуется в динамическом переводческом контексте ответа, т. е. диалога. Волошинов/Бахтин понимание относит к знаку, в то время как узнание - к сигналу: «Процесс понимания ни в коем случае нельзя путать с процессом узнания. Они - глубоко различны. Понимается только знак, узнается же - сигнал. Сигнал - внутренне неподвижная, единичная вещь, которая на самом деле ничего не замещает, ничего не отражает и не преломляет, а просто является техническим средством указания на тот или иной предмет (определенный и неподвижный) или на то или иное действие (также определенное и неподвижное!)» (Волошинов/БАХтин 2000: 404). ${ }^{4}$ Онтология знака предполагает его семантическую гибкость, т. е. порождающую семантическую силу, воплощенную в обновлении значения («понимание новизны» данной языковой формы; Волошинов/БАхтин 2000: 404) в разных, все новых и новых динамических контекстах диалогического перевода. Перевод касается и того перевоплощения, по ходу которого изначально усвоенная как себетождественная языковая форма ${ }^{5}$ в конкретной структуре высказывания, в «языке-речи» воспринимается как гибкий и изменчивый знак. Понятие «нормативно тождественных форм языка» таким образом сменяется понятием «совокупности возможных контекстов употребления данной языковой формы» (Волошинов/БАХтин 2000: 405). Такая совокупность возможных контекстов обновляющих актуализаций языковых форм - в духе определения понимания в своей неразрывности с ответом - имплицитно распространяется на все диалогические контексты, обязательно включающие в себя акт перевода контекста говорящего в контекст субъекта реплики - речь идет о диалогических контекстуальных переводах (к этому вопросу мы еще вернемся ниже). ${ }^{6}$

Тот факт, что процитированная выше концепция Э. Бенвениста (1966) в главном своем аспекте сосредоточения на речи-высказывании выявляет

${ }^{4} \mathrm{Cp}$. с рассмотрением сигнала и сигнализации Пятигорским в прагматическом контексте коммуникации с совсем другим подходом, и см. там отождествление с функциональной точки зрения сигнала и целостного текста (ПятигоРский 1962).

5 «Чистой сигнальности нет даже и в начальных фазах научения языку. И здесь форма ориентирована в контексте, и здесь она является знаком, хотя момент сигнальности и коррелятивный ему момент узнания наличны» (Волошинов/БАХТин 2000: 405).

${ }^{6}$ П. Гржибек интерпретирует в том числе и толкование Волошиновым/Бахтиным различения двух путей исследования значения определенного языкового элемента в русле противопоставления «словарного слова» и «темы», вырисовывающейся в контексте высказывания (ГржиБЕк 1995: 252-253). Помимо прочего по осмыслению концептуализации темы португальский исследователь Фабио Арези проводит параллель между концепциями значения в работах Бахтина и его научного круга и Бенвениста (см. ARESI 2011: 48-51). 
несомненную свою преемственность/смежность ${ }^{7}$ с указанной теорией бахтинского круга (1929) - ср.: «Семиотическое (знак) должно быть узнано, семантическое (речь) должно быть понято» (БЕНВЕНИСт 1974: 88), - может отвлечь внимание от значительного различия, обнаруживаемого в двух подходах к дифференциации феноменов семиотического и семантического. Дело в том, что если в работе «Марксизм и философия языка. Основные проблемы социологического метода в науке о языке» семантическому знаку противопоставлен семиотический сигнал, то согласно изложению Бенвениста семиотическое и семантическое воплощают два компонента того специфического способа двойного означивания (ср.: «signification»), которым язык передает значение. Два способа различаются не в русле сигнальности (ср. узнавание у Волошинова/Бахтина) vs. знаковости (ср. понимание-ответ; там же). Оба способа присущи языку, но семиотическое означивание принадлежит к знаковости, в то время как семантическое проявляется в речи. Основной принцип различения двух способов обнаруживается в дальнейшем прочтении элементов определений: «Семиотическим называется способ означивания, присущий языковому знаку и придающий ему статус изелостной единицыы. [...] Говоря о семантическом способе, мы имеем в виду специфический способ означивания, который порождается речью», ${ }^{8}$ когда «смысл [,,речевое намерение“"] реализуется как ичелое» (БЕнвенист 1974: 87-88). Противопоставлены, следовательно, не сигнал («узнавание» : «себетождество») и знак («понимание»/«ответ» : контекстуальное обновление значения в диалогическом переводе), а знак в смысле выбора целостной единицы (семиотическое означивание) и семантическое означивание, приводящее к осмыслению целостного высказывания. Так как означивание определяется как принадлежащее к языку свойство передавать значение, в итоге оба способа подразумеваются как виды семантизации, т. е. семиотизация в этом смысле концептуально расположена внутри семантизации. Два способа означивания предполагают лишь два подхода к языковой семантизации - первый касается «выделения и идентификации единиц, описания их различительных признаков, отыскивания все более и более тонких критериев их разграничений» (88). Суть отыскивания дифференциальных признаков никак не сводится к игнорированию различных контекстов, так как этот процесс, по определению Бенвениста, происходит так, что «каждый знак будет находить все более четкую характеристику присущего ему означивания внутри некоторой совокупности или множества знаков» (88). Получение четкой характеристики в процессе опознания знака включает себя сравнивание знака «либо с частично сходными означающими..., либо с близкими означаемыми» (87), а это и значит опре-

${ }^{7}$ См. Вяч. Вс. Иванов: «Mikhail Bakhtin was the first to discover a difference between an abstract linguistic system of signs and a concrete utterance in which each sign gets another function due to its role in the whole of discourse. [...] later this distinction was rediscovered by the great French linguist Émile Benveniste» (IvANOV 1999: 3).

${ }^{8}$ Курсивные выделения в цитатах - если не оговорено иначе - по ходу всего изложения в данной статье принадлежат нам - К. К. 
деленную семантическую контекстуализацию знака, в результате чего знаковый идентитет четко вырисовывается на фоне семантического определения (по сути дела в обоих случаях сравниваются смыслы с уклоном на двухстороннее толкование знака: с учетом слова как означающего и как носителя означаемого). В русле такого определения знак выявляет не лишь себетождественность (как сигнал на этапе узнания у Волошинова/Бахтина), но и «чистое тождество с самим собой и чистое отличие от любого другого», и благодаря этим своим свойствам он «является означивающей основой языка, необходимым материалом выражения» (88). Из этого явствует, что согласно концептуализации семиотического означивания (по сути дела семиотической семантизации), у Бенвениста выделяется контекст сходных и близких означающих и означаемых, т. е. нахождение статуса знака в более обширном семантическом контексте, позволяющем отметить «чистое тождество и чистое отличие» знака, превращенного именно благодаря такой своей семантической дифференциальной специфике, в «целостную единицу» в системе языка. Определение «тождества» и «отличия» знака, как мы видели, подразумевает семантическое испытание знака в контексте других знаков, что и значит, что семиотическая идентификация знака предполагает его определение по связям элементов языковой системы.

Именно по критерию характеристик реляций между элементами знаковой системы семиотическое означивание отличается от семантического. Этот второй способ порождения смысла ориентируется на речевое высказывание. Производимое сообщение с точки зрения характеристики семантического означивания в глазах Бенвениста имеет свою специфику в том, что в нем проявляется не лишь простая последовательность единиц, «которые допускали бы идентификацию каждая в отдельности; смысл не появляется в результате сложения знаков, а как раз наоборот, смысл [,„речевое намерение реализуется как целое и разделяется на отдельные ,знаки“, какими являются слова» (88). Речь здесь идет о принципе формирования дискурса и его сегментации. Определяется примат целостного означивания, не сводящегося к индуктивной последовательности отдельных слов. Вместо этого подчеркивается дедуктивное деление целостного смысла на составляющие знаки. Такое абстрактное определение индукции (в смысле от части к целому) и дедукции (в смысле от цзелостного к части) само по себе не дает объяснения тому, для чего служит сегментация и как она происходит. На эти вопросы ответ предлагается путем противопоставления характеристики референтности в рамках двух способов означивания: «Семантическое означивание основано на всех референтных связях, в то время как означивание семиотическое в принципе свободно и независимо от всякой референции. Семантический аспект принадлежит к сфере высказывания и миру речи» (88). В приведенном определении речь с продуктом высказывания осмысляется с точки зрения референтных связей, которые лучше поддаются регулированию, в то время как семиотическое означивание как бы складывается независимо от всякой референции. Так как факт референтности недвусмысленно признан 
в концепции Бенвениста в том месте характеристики семиотического означивания, где говорится об определении знака в контексте сходных и близких означающих/означаемых, нельзя предположить, что в утверждении «... означивание семиотическое в принципе свободно и независимо от всякой референции» скрывается полное отрицание референтности. ${ }^{9}$ Данное утверждение следует толковать как раз в свете противопоставления, согласно которому в высказывании семантическое означивание основано на «всех референтных связях». В данном контексте изложения это не может означать иное, как подчеркивание тех связей, которые уловимы путем дедуктивного означивания (сегментации) целостного высказывания. (В этом свете и следует уточнить смысл сегментации и дедуктивности - под ними подразумевается осознание многосторонности референтности, порождающей целостный смысл целостного высказывания, следовательно, указанная дедуктивность приводит к сегментации в области толкования и дешифровки смыслопорождения.) Если семиотическое означивание позволяет идентификацию элементов языка, «каждого в отдельности», - хотя и сходные и близкие означающие/означаемые даже при такой идентификации составляют именно семантический контекст для определения смысла знака, - то способ семантического означивания в целостном высказывании обязательно требует осмысления «всех связей», от которых оно не может быть свободным и независимым. Все референтные связи означают множество внутренних референтных аспектов, которые открываются при дедуктивном делении целостного высказывания на его составляющие знаки.

В конечном итоге основные различительные признаки двух способов означивания в работе Бенвениста сводятся к следующим аспектам: 1) сила семантической контекстуализации; и 2) тип, множественность и связанность внутренней референтности (в случае семиотического означивания контекст сходных и близких означающих/означаемых в системе языка, без обязательного общего контекста всех отдельных компонентов; в случае семантического означивания - многообразные внутренние взаимосвязанные референтные отношения внутри высказывания, которые расшифровываются путем неизбежной для толкования сегментации; в этом втором способе подразумевается имплицитное противопоставление внутренней и внешней референции). Оба способа означивания принадлежат к сфере семантизации, неотъемлемой частью которой является семиотизация. В итоге пройденного

${ }^{9}$ Cp. статью Анри Мешонника на тему «sémantique sans sémiotique», с аргументацией несостоятельности примеров Бенвениста для утверждения отсутствия семантики при семиотичности (MESCHONNIC 1997: passim, особенно: 313, 314), и подобным образом, семантическое толкование не должно снимать проблему семиотичности; относительно художественного произведения см. особенно: «Où le rapport entre sémiotique et sémantique devient interne à l'oeuvre, et du coup un critère de ce qu'on peut appeler une oeuvre. L'oeuvre est toujours "particulière » si elle est à la fois sa sémantique et sa sémiotique. Autre manière de dire finalement que sémiotique et sémantique sont une seule et la même - tension à la Héraclite - et qui révèle la tension interne au sémantique sans sémiotique» (MESCHONNIC 1997: 316). К данному вопросу мы еще вернемся. 
толкования разделения области семиотического и семантического можно прийти к выводу, что семиотическое и семантическое означивания определяют разные меры и типы семантической контекстуализации и ее системности. Также они предполагают разные направления смыслопорождения индуктивной и дедуктивной логикой. Но как способы семантизации они связаны именно с семиотической природой языка. Нельзя забывать о том, что когда Бенвенист вводит в свое изложение принцип двойного означивания, он стремится объяснить доминирующее положение языка среди других означивающих систем. В уникальной способности языка к такому двойному означению он распознает то единственно приемлемое объяснение для превосходства языка над другими знаковыми системами, которое вытекает из осознания «семиологического принципа» языка («и только семиологический принцип может объяснить истоки этого превосходства», 87).

Семиотическое и семантическое, следовательно, у Бенвениста получают разъяснение, позволяющее видеть иерархическую систему. Область семантического двояко размещена в сфере семиотического. Сначала в русле зарисовки исторического контекста эволюции наук. В этом контексте лингвистику, которой принадлежат и все аспекты семантики, Бенвенист вслед за Соссюром однозначно определяет как компонент семиологии (73). А затем, уточняя способность языка к двойному означиванию (см.: сфера семантизации) как семиологический принцип, заложенный в структуре и функционировании языка, он подтверждает семиотическую онтологию языка. Введением в данные рамки интерпретации противопоставления семиотического и семантического, во-первых, создается иерархия для обоих понятий (семантика появляется внутри семиотики, а затем она содержит в себе как семиотическое, так и семантическое); во-вторых, сложно проецируя друг на друга понятия и аспекты семиотического и семантического действия языка, толкуемого на разных уровнях понятийной иерархии, Бенвенист сильно акцентирует их взаимосвязь, т. е. необходимость сочетания проблематики смыслопорождения с вопросом о семиотическом функционировании определенной знаковой системы. Однако указанная двухступенчатая постановка проблемы (в рамках семиотики $\rightarrow$ семантика, а в рамках последнего $\rightarrow$ различение семиотического и семантического), исключает любую возможность схематичного толкования.

На данном этапе изучения указанной понятийной иерархизации следует обратить внимание и на следующее: Волошинов/Бахтин и Бенвенист ставят проблему семиотизации и семантизации в два важных контекста. Волошинов/Бахтин изучает данные явления в русле проблемы коммуникации через осмысление вопроса нормативности употребления языка. Бенвенист выдвигает дилемму двух типов означивания, чтобы суметь дать точный ответ на вопрос, чем обусловлена способность языка воплощать универсальную семиотическую матрицу, такую моделирующую структуру, «у которой другие структуры заимствуют основные свойства устройства и функционирования», в результате чего «язык выступает как интерпретант по отношению к любой 
означивающей системе» (87). Как было сказано, такое превосходство языка в кругу других означивающих систем Бенвенист объясняет его «семиологическим принципом» (87), осознанным в том факте, что «язык - это единственная система, где означивание протекает в двух разных измерениях. [...] Привилегированное положение языка заключается в его свойстве осуществлять одновременно и означивание знаков и означивание высказывания. Отсюда и проистекает его главная способность, способность создавать второй уровень высказывания, когда становится возможным высказывать нечто означивающее о самом означивании. В этой метаязыковой способности и лежит источник отношения интерпретирования, благодаря которому язык включает в себя другие системы» (88-89). (Тут предполагается, что язык своей интегральной способностью включать в себя разные языки и системы обязан той своей способности, благодаря которой он создает и метаопределение того, как его семантическая система относится к включенной им самим семиотической системе - к данной проблеме вернемся в том месте настоящей работы, где вслед за развитием мысли Бенвениста, в качестве высказывания будем интерпретировать уже тексты и художественные произведения.)

Следует лишний раз подчеркнуть, что проблема означивания входит в круг вопросов семантической концептуализации знака, и в этом смысле семиотическое и семантическое не диаметрально оппозиционные категории, а два аспекта интерпретации семантической способности языка в рамках его «семиологической» природы. В изучаемой работе последовательно различаются названные два аспекта на основе критерия цзелостности - в семиотическом аспекте означивания в данной теории это касается интерпретации знака в своем статусе «целостной единицы» языка, а в случае сообщения, речь идет о целостном смысле высказывания как цуелого, от которого отправляется дедуктивная сегментация (толкование) всех внутренних референтных связей. Много внимания уделялось выше также и различению двух типов семантических контекстов по мере их величины и структуры (ср.: контекст сходных и близких означающих/означаемых в языке vs. контекст целого высказывания со всеми его референтными связями). В свете всего рассмотренного утверждение Бенвениста оказывается весьма последовательным: следует подумать о двух познавательных областях, которые влекут за собой два разных ряда понятий (88). С ними и связывается то противопоставление, из которого исходит толкование целой концепции ученого, и которое суммировано в тезисе: «Семиотическое (знак) должно быть узнано, а семантическое (речь) должно быть понято». Тем не менее, сама семантическая постановка проблематики означивания вполне противоречит возможности исключения понимания из любых из двух сфер. Семантика не может представляться без акта толкования понимающим субъектом, следовательно момент узнавания нельзя оторвать от понимания, ${ }^{10}$ точнее говоря, нельзя вырвать из толкования

${ }^{10} \mathrm{Cp}$. с осмыслением Мешонником дальнейшего развития конфликта как «кризис понимания» в художественном дискурсе (MeSCHONNIC 2011:322). 
целостного процесса понимания, из чего вытекает, что противопоставление узнавания пониманию требует значительного нюансирования. Подобным образом кажется амбивалентным определение Бенвенистом старого («предыдущего») и нового («настоящего»), когда по ходу уточнения понятий узнавания и понимания он утверждает: «Различие между узнаванием и пониманием связано с двумя отдельными свойствами разума: способностью воспринимать тождество предыдущего и настоящего, с одной стороны, и способностью воспринимать значение какого-либо нового высказывания, с другой. При патологических нарушениях речевой деятельности эти две способности часто разрываются» (88). Во-первых, здесь эксплицитно указывается совместное наличие двух когнитивных операций в нормальной речевой деятельности, что и значит, что «семиотическое (знак) и семантическое (речь)» нельзя различить по признакам узнавания и понимания, так как речь должна включать в себя оба аспекта; к тому же каждое понимание интегрирует узнавание как определенный этап в развертывании когнитивного процесса. Вовторых, ко всему этому добавляется другая двусмысленность, вытекающая из следующего. Такое же предположение сочетания в познавательном акте двух моментов - 1) узнавания тождества предыдущего и настоящего, т. е. восприятия континуитета знака (нам следует уточнить: знака со своим значением, ведь знак, согласно никакой его концептуализации, не может ограничиваться своей означающей стороной - К. К.) и 2) восприятия нового смысла (в значении нового высказывания, ср. противопоставление Волошиновым /Бахтиным сигнала и знака) - лежит, хотя и менее маркированно, также в основе определения статуса знака как целостной единицы, вокруг которого Бенвенист строит концепт семиотического означивания. Ведь когда говорится о двойном моменте в семиотическом означивании - 1) решение вопроса о существовании определенного знака, 2) сравнение знака с частично сходными означающими и с близкими означаемыми (87-88), - то предполагается сравнение старого, известного с новым, как и в плане означающего, так и в плане означаемого. Все это исключает возможность примирения с диаметральным противопоставлением как узнавания и понимания, так и семиотического и семантического, и в конечном счете - с противопоставлением характера знака (язык) и свойства речи (высказывание) по критериям оппозиции семиотизации и семантизации. Не случайно Ю. С. Степанов обращает внимание на противоречивость и тусклость в определенных аспектах концепции Бенвениста, и тем более он прав, что в данной работе оба способа означивания принадлежат к самому языку, который интерпретируется как знаковая система, обладающая превосходством над другими знаковыми системами: «...Бенвенист развивает точку зрения, согласно которой семиотический принцип (более узкой формулировкой которого является принцип знака) характеризует не язык в целом, а лишь один аспект языка. Существует иной принцип, семантический принцип, характеризующий иной аспект языка» (СтеПАнов 1974: 421). «Мысль Бенвениста, - продолжает Степанов, остается не вполне ясной, так как, провозгласив сначала разделение двух 
принципов, из чего вытекало бы, что лингвистика не совпадает с лингвосемиотикой, или семиологией языка, так как имеет в своем ведении весь аспект языка, основанный на принципе не семиотическом, а семантическом, он в конце статьи говорит о будущем слиянии лингвистики и семиотики в рамках „второго поколения семиотики“. Это различение и резкое разграничение двух принципов остается личной точкой зрения Бенвениста» (СТЕПАНОВ 1974: 421). Степанов говорит далее, что причина, по которой Бенвенист не может критически преодолеть свою названную первую точку зрения на отношение лингвистики к семиотике, состоит в том, что он придерживается изучения систем, основанных на соссюровской концептуализации знака как произвольного. Именно с теорией произвольности знаков, строящих системы (причем до «такой высокой ступени произвольности, как язык, или еще высшей»), связано, по мнению Степанова, само разделение семиотического и семантического принциПов (СТЕПАНОВ 1974: 421). ${ }^{11}$

Вернемся к определению «второго поколения семиотики» в самом бенвенистовском тексте. Там знак и речь имплицитно противопоставлены как область структуры и функционирования (в противоположность интерпретированной Бенвенистом соссюровской идее, согласно которой знак - это тот единственный принцип, от которого зависит и структура языка и его функционирование). Поэтому указывает Степанов, что постановка проблемы Бенвенистом в данной области соответствует тому, к чему французская семиотика пришла к 1969 году, совершая сдвиг от семиотики языка (ср. статичная, стабильная система) к семиотике речи (ср. динамика формирования), шире говоря: от семиотики систем к семиотике текстов. Но следует отметить, что́ именно Бенвенист подчеркивает, оценивая необходимость найти путь от знака к речи - по нашей концептуализации и терминологическому словарю: от знака в статичной системе к знаку в своем динамическом функционировании, воплощающемся в высказывании/тексте семиотического характера, который именно своей динамикой порождает свой семантический мир. Ученый четко формулирует самый существенный вопрос, по его мнению не решенный Ф. Соссюром: «...вопрос именно в том и состоит, чтобы выяснить,

${ }^{11}$ Более систематически анализирует противоречия Бенвениста Ирен Тамба-Мец в своей статье, в которой толкование противопоставления семиотического и семантического ставится в контекст формирования понятийного и терминологического определения таких языковых реалий как сам язык, слово, знак, предложение («phrase»; ср. высказывание). Исследовательница рассматривает развитие указанных определений в период с 1962 г. по 1969 г. Так как учет предшествующих статье «Семиология языка» определений не заставляет нас модифицировать изложенную в настоящей статье аргументацию, проблему генезиса терминов оставим в стороне (cp. TAMBA-MECZ 1984). Ученый в отношении проблематики произвольности знака принимает иную позицию, когда, ссылаясь на работу Г. Сербата, она согласна с тем, что Бенвенист модифицировал понятие произвольности знака, по сравнению с его толкованием у Соссюра: «Et ce n'est pas un hasard si E. Benveniste a „corrigé” F. de Saussure, comme l'a bien montré G. Serbat, en «supprimant l'arbitraire fondamental au coeur du signe, pour mieux l'instituer entre le signe et la réalité extérieure » $<$ Serbat G. Saussure corrigé par Benveniste : dans quel sens. In: Lire les Linguistics. Raison Présente 62. Paris, 1982. 27>» (TAMBA-Mecz 1984: 194). 
можно ли, и если можно, то как, от знака переходить к речи». Принимая во внимание, что от замкнутого мира знаков «в высказывании нет перехода ни путем образования синтагм» ${ }^{12}$ или каким-либо другим путем, а между ними обнаруживается «непроходимая грань», предлагаются две области изучения языка отдельно, семиотическая и семантическая. Стремление к преодолению соссюровского понимания знака как единственного принципа структуры и функционирования в данном тесном контексте проявляется как старание вычеркнуть значительный недостаток, и путем распространения идеи языкового знака «на целое речевое произведение... не вступить в противоречие с определением знака как минимальной единицы» (89). ${ }^{13}$ В этом свете в более нюансированном виде открываются два дисциплинарных направления, предложенных Бенвенистом, чтобы совместить семиотические и семантические исследования. Одно из них - внутриязыковой (интралингвистический) анализ «в направлении нового измерения означивания, в плане речевого сообщения» (89). Речь идет об исследованиях семантического означивания, методологический уклон которых довольно конкретно можно отождествить в основе точного определения данного способа означивания в статье. В круг аспектов примата такого исследования - как мы подробно говорили об этом - входит ориентация на целостный смысловой мир высказывания, дедуктивная сегментация, учет умножения семантической контекстуализации и сосредоточенность на всяческих внутренних референтных связях. Этот последний аспект ориентиров с установкой на выяснение «всех референтных связей» открывает путь и для методологического осмысления второго названного Бенвенистом исследовательского направления. Здесь отмечается надъязыковой (транслингвистический) анализ с уклоном на толкование метасемантики, надстраивающейся над семантикой высказывания. Такому транслингвистическому анализу должны подвергаться не только простые тексты, но в выделенном месте - (художественные) произведения (см. французский оригинал: «dans l'analyse translinguistique des textes, des oeuvres» - BENVENISTE 1969b: 135; в русском переводе в этом месте стоит: «в надъязыковом [транслингвистическом] анализе текстов и художественных произведений» - БЕНвЕнист 1974: 89; в английском переводе, к сожалению, модифицируясь по сути дела исчезает указанное выражение, см.: «in the translinguistic analysis of texts and other manifestations through the elaboration of a metasemantics found on the

12 O вопросе синтагматизации, связанном с проблемой дискурсивной ассоциации и в конечном счете с интенцией высказывания, см. GUIGUE 2011, особенно: 156-162 (о парадигматизации ср. ТАмBA-MECZ 1984: 195-196).

${ }^{13}$ Тамба-Мец убедительно указывает на то, что у Бенвениста существуют два определения знака, подобно тому, как существуют два понятия языка. Она цитирует то место из PLG1 (BENVENISTE 1966: 129), где утверждается, что высказывание не может считаться знаком, так как критерием знаковости является и интегральная способность знака (согласно которой он способен включаться в единицу более высокого уровня системы, подобно тому, как морфема интегрируется в слово, а слово в предложение) (ТАMBA-MECZ 1984: 190-191; cp. BENVENISTE 1966: 123). 
semantics of enunciation»-BENVENISTE 1981: 21). В этих двух направлениях обнаруживается перспектива «семиологии второго поколения», понятие и методы которой смогут содействовать развитию других ветвей общей семиотики. Вопрос в том, что́ точно понимается под семиотикой/семиологией «второго поколения», и почему отождествляется и называется такой подход именно семиотическим («семиологическим»)?

Ответ напрашивается с двух точек зрения. Первая связана с упомянутым расширением учета «всех референтных связей» внутри высказывания. Говорить на втором этапе определения дисциплинарных направлений уже эксплицитно о текстах, о произведениях, а не имплицировать лишь высказывания (в смысле речевого сообщения) - это придает новый смысл определению «всех референтных связей», ведь тут названа метасемантика как система, надстраивающаяся над высказыванием (система). Метасемантика своеобразно расширяет круг определения «референтных связей», так как здесь яснее, чем в общем определении характеристик семантического способа означивания указывается конкретная форма возможной референтной связи, когда допускается видеть референтное отношение семантики и метасемантики внутри систем языковых высказываний и текстов. (При этом обязательно следует учитывать, что выстраивание метасемантического слоя предполагает означивающую систему семиотической природы.)

Если в едином контексте целой статьи, общем для двух частей изложения Бенвениста, подвести итоги, с одной стороны, определениям семиотического и семантического способов означивания, присущих языку как системе и различным формам его речевого произведения, а с другой, - характеристикам двух предложенных исследовательских направлений, отмеченных в целях выхода из того тупика, что между знаком и высказыванием «непроходимая грань», то следует остановиться именно на концепте метасемантики. Он наглядным образом коррелирует с объяснением Бенвенистом того, что именно способностью языка передавать значение двойным - семиотическим и семантическим - означиванием обусловлена его особенность выступать как «интерпретант по отношению к любой означивающей системе» (87). Такую одновременную способность языка к означиванию как знаков, так и высказываний и в терминологическом плане легко было бы перевести в понятие метасемиотики (язык как знаковая система интерпретирует другие [языковые] знаковые системы), в случае утверждения, что язык обладает способностью «создавать второй уровень высказывания, когда становится возможным высказать нечто означивающее о самом означивании. В этой метаязыковой способности и лежит источник отношения интерпретирования, благодаря которому язык включает в себя другие системы» (88-89). Если до сих пор мы подчеркивали, что как интерпретация семиотического, так и семантического способа означивания разрабатывается в русле проблематики семантизации, то далее поставим еще раз ударение на другую методологическую ориентированность толкования названных типов смыслопорождения. Когда Бенвенист связывает способность языка к выстраиванию метасемантических 
формаций в виде высказываний, он предполагает, что именно семиотическое (семиологическое) действие языка, т. е. его знаковый характер обеспечивает этому твердую основу. В этом духе он дает ответ на вопрос, чем обусловлена специфика языка становиться «универсальной семиотической матрицей» и плодотворной «моделью» для других знаковых систем, и уметь действовать «интерпретантом по отношению к любой означивающей системе» (87). «Только семиологический принцип может объяснить истоки этого превосходства» (87) - звучит четкий ответ.

Продолжая параллельно читать две взаимосвязанные части в изложении концепции Бенвениста, описание своеобразия языка, проявляющегося в двойном означивании - знака и высказывания, - и начертание перспектив двух направлений исследования языка с такой способностью, и все это ставя в изначальный контекст постановки вопроса об уникальной способности языка быть интерпретантом других знаковых систем, возникает возможность видеть во второй части изложения ученого сравнительно четкое определение пути перехода от знака к высказыванию, а именно в концептуализации метасемантического и - в духе сказанного позволяется думать, что также метасемиотического действия языка. Для этого Бенвенист очерчивает дисциплинарные перспективы в исследовании высказываний, вообще текстов и специально: художественных текстов («textes» и «oeuvres»), т. е. речевых произведений разной семиотической системности. Решение вопроса предлагается именно с учетом разных форм речевых произведений (когда имплицитно, в глобальном контексте целостной статьи, различаются высказывание и текст, а рядом с последним стоит произведение), при том, что исследование семантического означивания вовлекается в круг проблемы метасемантизации и имплицитно метазнаковости. В русле сочетания двух «половин» изучаемой бенвенистовской концепции, можно прийти к смыслу перехода от знака к высказыванию в свете концептуализации такой референтной связи между ними, которая создает метасемантизацию знака, принадлежащего к системе языка. В то же время, метасемантизация четко определяется и по отношению к разным высказываниям и текстам, и даже предполагается способность языка стать метамоделью других знаковых систем. Благодаря такой глобальной рамке толкования метасемантизации и имплицитно: метасемиотизации (хотя Бенвенист термином метасемиотизации эксплицитно и не пользуется) переход от знака к высказыванию кажется обеспеченным, и не только в отношении знака как элемента абстрактной системы языка и компонента высказывания, но и между разными высказываниями и текстами и даже знаковыми системами. Связывающее звено, следовательно, сводится к идее об означивании предыдущего означивания как референта. Этим по сути дела снимается сложность, неоднозначность и противоречие постулирования явления семиотического и семантического, когда способность языка к смыслопорождению вовлекается в толкование своеобразного «семиологического» принципа языка, а далее указанный принцип означивания разветвляется на семантическое и семиотическое действия языка. 
Поскольку метасемантизация влечет за собой признание и осознание проявления принципа метасемиотизации (или метазнаковости), становится наглядным в теории Бенвениста неразрывность двух факторов способности языка и в том смысле, что путь от знака до высказывания или от высказывания в качестве знака ${ }^{14}$ до нового высказывания в качестве интерпретанта ${ }^{15}$

${ }^{14}$ Обратим внимание на то, что концепция Бенвениста основывается именно на понятийной, системной и функциональной неотождествимости семиотического значения знака в системе языка и семантического значения в дискурсе. Тем не менее, изложенное в статье никакого аргумента не приносит против факта, согласно которому семантическое предполагает знаковую форму, а в знаковом образовании воплощается семантика. См. еще раз статью Мешонника (ср. сноску 9), где интерпретируется поставленная Бенвенистом проблема «семантики без семиотики», которая характеризует артистические выражения, т. е. искусство (этим художественный текст у Бенвениста как бы отличался той же одномерностью означивания, как и системы, которые, в противоположность языку, имеют единственно семиотический характер). Однако Мешонник убедительно указывает, что и упомянутые Бенвенистом знаковые системы следует толковать с двух сторон, с точки зрения семиотики и семантики, и, что еще важнее, в случае поэтического языка следует думать о новом, в индивидуальной форме созданном семантическом и семиотическом в произведении. Мешонник точно определяет, как он понимает по статье особенную семантику и семиотику в случае произведения: «Autrement dit, dans une oeuvre de langage, Benveniste aurait pu dire : "L'artiste crée ainsi sa propre sémantique » au lieu qu'il a écrit : «L'artiste crée ainsi sa propre sémiotique » (p. 58). Puisqu'il disait de l'artiste : « Il ne reçoit donc pas un répertoire de signes, reconnus tels, et il n'en établit pas un... » (p. 58)» (MESCHONNIC 1997: 311). В то же время, новое, индивидуально созданное семантическое связано с тем, что: «C'est sur une telle critique, inévitablement, mais sans la formuler, qu'ouvre, à propos de « la signifiance de l'art», la phrase : «Il faut en découvrir chaque fois les termes, qui sont illimités en nombre, imprévisibles en nature, donc à réinventer pour chaque oeuvre, bref inaptes à se fixer en une institution». (MESCHONNIC 1997: 318). Другими словами, языковое произведение (художественный текст) творит индивидуальный, неповторимый семантический мир, который следует в каждом случае отдельно обнаруживать, устанавливая в нем условия смыслопорождения, численно бесконечные и непредсказуемые по своей природе, т. е. следует их творчески создавать для каждого отдельного произведения, потому что они не входят ни в какую языковую институционализацию. Таким же образом нельзя причислять художественное произведение и к феномену установленной знаковости общего языка, так как автор и произведение не получают в готовой форме репертуар знаков, распознаваемый как таковой, и не создают из такого репертуара какой-то определенный знак, выбирая знаковость (ср. БЕнвЕниСт 1974: 83-84). В этом духе следует понимать утверждение Бенвениста, согласно которому необходимо различать две системы - в одной из них свойство означивания зависит от внутренних связей («внутри данной композиции»), в которые «первичные элементы» [общеязыковые знаки К. К.] «могут вступать друг с другом», т. е. означивание основывается на внутренних отношениях, и в этом смысле приводится «замкнутый мир» (хотя и смыслопорождающие условия бесконечны); - во второй, «означивание присуще уже первичным элементам в изолированном состоянии». Речь в оригинале далее идет не о том, о чем говорится в русском переводе, что в этом втором виде означивание «неотделимо от самих знаков», а о том, что означивание здесь «inhérente aux signes eux-mêmes» (BENVENISTE 1969b: 129). Это имеет большое значение, когда речь идет о выяснении концепта знака и знаковости (семиотичности) у Бенвениста. Ведь здесь ученым наглядно понимается то, что в художественном произведении, где пересоздается семантика, снимается устойчивость общеязыковых первичных знаков (т. е. семиотика общего языка как абстрактной системы). Подразумевается вторичность, в связи с которой ничего конкретного не говорится о том, как она относится к первичности, лишь подчеркивается то, что творятся бесчисленные новые, непредвиденные смысловые связи, в каждом случае индивидуальном художественном языковом творчестве, которое порывает устойчивую связь, осно- 
ванную на семиотическом соглашении (можно спокойно перевести это понятие в термин $c e-$ миотической условности, в которой содержатся устойчивые правила отношений первичных означающих и означаемых данного языкового коллектива; - постановку вопроса конвергенции лотмановских и бенвенистовских идей в рамках проблематики соотношения первичных и вторичных языков и моделирующих систем, см. GRAMIGNA 2013; о семиотической условности в культуре, см. ЛотМАН-УСПЕНСКИй 2000). Логично речь не может идти о том, что во втором случае приоритет имеет знак, в то время как из художественного текста исчезает первичность знака. Получает сильный акцент иная мысль. Устойчивость первичной, общеязыковой семиотической условности исчезает при внутренних условиях знаковых связей, порождающих семантику. Ведь знак остается знаком и внутри произведения. Он функционирует лишь при измененных семиотических условиях (условиях установления отношения означающего-означаемого или объекта, репрезентамена и интерпретанта). Итак, говоря с точки зрения означивания о знаке, исчезает не знаковость, а лишь поддается трансформации тот смысл знака, который предшествует его текстовому перетворению в непредвиденных новых связях. В этом свете и следует опять обратить внимание на мысль Бенвениста о художнике, который на холсте создавая соотношения цветов, не имеющих однозначных референтов, «творит свою собственную семиотику» тем, что создает индивидуальные смысловые условия в композиции, т. е. у него индивидуальным языком и означиванием порождается семантика. Но так же происходит смыслопорождение и тогда, когда изменяется первичная семантика какого-то языкового знака в литературном произведении, в том смысле, что и тогда перевоплощается семиотичность в данном высказывании по отношению к общелингвистической семиотичности. И так как перетворение семиотичности содержит в себе порождение художественной семантики, Мешонник полностью прав, когда добавляет, что Бенвенист мог бы сказать, что художник творит «свою собственную семиотику». Так и есть, в этом месте изложения семиотика и семантика неотделимы, и именно поэтому нельзя предполагать, что когда Бенвенист затрагивает проблему трансформации включенного в знаке первичного значения, то в соответствии с русским переводом утверждается, что лишь в языке как абстрактной системе означивание неотделимо от самих знаков, в то время как в художественном произведении то же означивание зависит от отношений знаков. Само собою разумеется, что художественное означивание зависит и от самих знаков, которые вступают в отношения. Вопрос является кардинальным, так как различение между семиотическим и семантическим означиваниями в случае последнего как бы апеллировало к отодвижению на задний план феномена знаковости, в то время как на самом деле определяется лишь другая системность знаковости и семиотичности (т. е. другое отношение между знаком и значением). Новую семиотичность, сотворенную в художественном произведении, Мешонник соотносит с понятием «перформативного», и представлением Гумбольдта о языковой активности, в чем и он находит родственное с бенвенистовским различением принципа «простой последовательности единиц, которые допускали бы идентификацию каждая в отдельности» и принципа, когда «смысл (,речевое намерение“) реализуется как целое и разделяется на отдельные „знаки“, какими являются слова» (БЕнВЕнист 1974: 88): «Conception remarquablement proche d'une formule fameuse de Humboldt : «Dans la réalité, le discours n'est pas composé de mots qui le précèdent, mais ce sont les mots au contraire qui procèdent du tout du discours » - In der Wirklichkeit wird die Rede nicht aus ihr vorangegangenen Wörtern zusammengesetzt, sondern die Wörter gehen umgekehrt aus dem Ganzen der Rede hervor », W. von Humboldt, éd. Cotta, III, p. 448 ; éd. de l'Académie, VII, p. 72 ; éd. du Seuil, Introduction à l'œuvre sur le Kavi, p. 213» (MESCHONNIC 1997: 322). См. также о парадоксе предположения асемиотичности формулы «семантики без семиотики» («le fonctionnement asémiotique du langage») (MESCHONNIC 1997: 322-323). См. Клоэ Лаплантине о своеобразии семантической активности как авторской интенции субъекта языка, в понимании Бенвениста, художественного языка, и см. также приведение в соответствие с этими понятиями идеи инвенции формы (в противоположность формалистской идеи повтора) выяснением контекста работы над поэтикой Бодлера (1967), от которой, по мнению исследовательницы, нельзя оторвать всю постановку проблематики поэтики художественных текстов, наглядно присутствующей в изучаемой статье «Семио- 
и т. д. в языковой культуре закономерно обеспечивается. Из этого вытекает, что в исследовании формирования речевых произведений как означивание знака, так и означивание высказывания постоянно вступают в реляцию, и в этом своем аспекте они не требуют учета «двух разных рядов понятий, двух познавательных областей» (88). Наоборот, существует такой подход к связыванию означиваний знака и высказывания, который, как Бенвенист утверждает в конце своей статьи, опирается на «новый аппарат понятий и определений» (89). Однако, как выяснятеся при дальнейшем чтении изучаемой работы Бенвениста, такой «новый аппарат понятий и определений» служит вовсе не лишь отдельному рассмотрению семантической области (88). Наоборот, нахождение пути от знака к высказыванию требует признания на новых основаниях одновременно семиотической и семантической натуры каждого знака и высказывания как целостного знака. Такие новые основания концептуализируются Бенвенистом, когда он говорит о новом дисциплинарном идентитете семиотики в направлении «семиологии второго поколения». Согласно логике целостного изложения двух частей концепции, эта новая семиотика уже не должна противопоставлять семиотическое и семантическое в рамках исследования форм семантизации, основанной на семиотическом принципе языка. Так как семиотическое, знаковое $a b$ ovo включает в себя семантическое, выражаемое языком знаков, настоящим вопросом выступает динамика семиотических и семантических перевоплощений в неразрывности их взаимосвязи и взаимоинтегрированности, которая проявляется как в знаке в качестве элемента языка, так и в высказывании в качестве метасемантической и метасемиотической культурной формы знака языка. (Приблизительное определение понятия динамики в этом контексте отсылается к формулировке Бенвенистом вопроса о том, «можно ли, и если можно, то как, от знака переходить к речи»; при новой формулировке вопроса, на наш взгляд, следует уже добавить, что целое высказывание как референт тоже может пониматься знаком.)

логия языка» (LAPLANTINE 2011). Статья посвящается A. Мешоннику, который акцентировал в вышеуказанной своей работе значительность формулирования программы поэтики языка. Такая поэтика - как обнаруживается в настоящей статье, и как подтверждают труды Лаплантин, специалиста бенвенистовской работы о Бодлере, а также идея Мешонника - выдвигает вопросы семантики литературного дискурса в таком ракурсе, который, как мы видели, даже в парадоксальной своей формулировке «семантика без семиотики» не может обойтись без осмысления литературной семиотичности. Концепцию Бенвениста в том широком контексте, который показывает исследование Лаплантине, однозначно следует включить в область литературной семиотики (об оценке Мешонником Бенвениста в работе «Pour la poétique II [1973]» cм. ADAM 2011: 132-133). См.: «Partant de Benveniste, on peut mieux distinguer l'opposition et l'interaction entre écriture et littérature. Car écriture est plus proche du sémantique que du sémiotique, mais ell crée à son tour du sémiotique, en produisant ce qui devient littérature, - elle ne l'a pas toujours été» (ADAM 2011: 132). См. далее в этой статье связь бенвенистовской теории с исследованием Тодорова, Кристевой и Барта.

${ }^{15}$ См. связь данной проблемы с «дешифровкой» в научном творчестве Е. Фарыно, например: «Дешифровка, ведущая к коду, имеет смысл не как реконструкция системы (ее единиц и грамматики), а именно как раскрытие моделирующего (семиотического) содержания этого кода» (ФАРЫно 1989, ср. ФАРЫНО 1988). 
В духе этого проливается новый свет и на изначальное толкование Бенвенистом знака с точки зрения его статуса целостной единицы языка, которому противопоставлено высказывание в произведении речи, взятое в своем целостном воплощении. Ведь метасемантическая и метасемиотическая натура произведения речи позволяет нам увидеть новое высказывание как целостный метазнак старого знака, который, со своей стороны, интерпретируется в семантическом плане. А современная семиотика культуры уже обладает надежной традицией толкования множества внутренних и взаимопроецированных референтных связей знаковых систем, в рамках которых происходят сложные процессы метасемантизации. ${ }^{16} \mathrm{~B}$ конечном итоге целостное изложение концепции Бенвениста полностью снимает противоречия, сводящиеся к любому противопоставлению семиотического и семантического смыслопорождения, при тех условиях, если позволяется интерпретировать метасвязи в рамках соотношений (референтностей) знаковости и метазнаковости. Правда, семантика текста культуры не обнаруживается в исследовании, предполагающем, что расширение семантического измерения прочтения текста, возможно, «отлично от плана, связанного со знаком, то есть семиотического» (89). Чтобы такое утверждение стало правдивым, нужно переименовать семиотику, что и делает Бенвенист, отмечая перспективы «семиологии „второго поколения“"» (89). Но эта «новая» семиотика, в том числе и семиотика художественных текстов, в своей развитой форме сохраняет свой контекст теории коммуникации и акцентирует значение сложных процессов создания культурных текстов и метатекстов (нельзя забывать, что в художественном тексте переоценивается как знак в качестве целостной единицы языка, так и каждое высказывание толкуется в развитии связей знаков и референтов). Акцент в этом контексте теории коммуникации для науки о знаке (и целостной семиотики) может перемещаться с вопроса сдвига нормативности знака ${ }^{17}$

${ }^{16}$ По поводу вопроса семиотизации семантики обращаем внимание на значительную дилемму, сформулированную в статье И. Тамба-Метц по ходу ее толкования понятия интралингвистического в работе Бенвениста (cp. BENVENISTE 1966), которое она вводит в реляцию с понятием не транслингвистического, а экстралингвистического. Под экстралингвистическим понимаются прагматические аспекты семантизации в ситуации создания высказывания (ср. ссылку исследовательницы на Рикёра, выделяющего прагматические аспекты высказывания). Тамба-Мец подтверждает, что интралингвистическое для Бенвениста означает семиотическое, но созданием высказывания, в котором по его тезису проявляется уже семантическая порождающая сила языка, согласно утверждению Тамба-Метц, управляют именно такие правила, которые извлекаются из системы языка. Здесь ставится вопрос о семиотизации семантики: «Et dans la mesure, où, selon la formule d'E. Benveniste, «qui dit 'sémiotique' dit 'intralinguistique' » (PLG II, p. 223) n'est-on pas en droit de dire qu'il se produit une sémiotisation du sémantique, « intra-linguistique »?» (TAMBA-MECZ 1984: 195).

${ }^{17} \mathrm{Cp}$.: «Каждый индивидуальный творческий акт, каждое высказывание - индивидуально и неповторимо, но в каждом высказывании есть элементы, тождественные с элементами других высказываний данной речевой группы. Именно эти, тождественные и потому нормативные для всех высказываний моменты - фонетические, грамматические, лексические - и обеспечивают единство данного языка и его понимания всеми членами данного коллектива» (Волошинов/БАХТин 2000: 390). 
в языке и в высказывании на вопросы культурных метамоделей (см. также Бахтина) как и знака в качестве целостной единицы (внутри текста ${ }^{18}$ ), так и высказывания или целостного текста (в рамках культуры), а также целостной знаковой системы (с уклоном в том числе и на научные тексты). Коммуникация в культуре/науке все сильнее осмысляется с установкой на проблемы автоописания. Возможно, что если принять знак в своем статусе целостной единицы языка как системы, с одной стороны, и высказывание, интерпретирующее знак в метасемиотическом и метасемантическом образованиях, с другой, это даст право истолковать тот выход из тупика, который искал Бенвенист, и нашел в указанном, хотя и, кажется, не максимально осознанном связывании знака с речевым произведением на уровне «металингвистики»/ «метасемантики»/метасемиотики, как и в семиотическом метамоделировании лингвистики в рамках семиотического автоописания языковой культуpbl. В этом смысле и свете можно вспомнить бенвенистовский тезис о том, что язык благодаря своей метаязыковой способности включает в себя другие системы. А семиотика через изучение динамики семантических и семиотических переходов в сложной системе культурных (в том числе и научных) своих текстов и метатекстов, призванных созидать живые семиотические формы автоописания культуры, действительно содержит ту лингвистику, которая изучает формы переходов от знаков к новым знакам в ходе процессов творения все новых и новых текстов культуры и форм их метасаментизации и метасемиотизации. Эта лингвистика, однако, неотделима от семиотики культуры. А в ней с данной перспективы особое место получает семиотика литературы со своим художественным языком и двойной динамикой взаимосвязи процессов семантизации и семиотизации.

\section{II}

Рассмотрим далее возможные подходы к проблеме семиотической и семантической динамики литературного текста, подводя итоги до сих пор обнаруженному возвращением к уже процитированной идее Анри Мешонника, который утверждает: «Исходя из Бенвениста мы лучше можем отметить оппозицию и взаимодействие между писанием и литературой. Так как писание более близко семантике, чем семиотике, но оно со своей стороны творит семиотику, создавая то, что становится литературой - которой оно не всегда было» (Pour la poétique II [1973], цит. по АрАм 2011: 132-132). Итак, семиотика в литературном дискурсе творится, подобно тому, как и художественная семантика, и в итоге семантика и семиотика ни в коем случае не противопоставлены, наоборот, в дискурсивном акте литература порождается именно

${ }^{18}$ Именно динамику постоянного движения в художественном тексте множества метареферентных связей можно опять привести в соответствие с имплицированной в концепции Бенвениста мыслью, указанной нами выше: язык своей интегральной способностью включать разные языки и системы обязан своему умению создавать и метаопределение того, как его семантическая система относится к включенной им самим семиотической системе. 
благодаря тому, что возникает семиотика. Эта новая семиотика - как идея несомненно вытекает из целостного изложения Бенвениста, согласно которому семантическая активность в качестве проявления интенции субъекта текста, и также совместное произведение формы самим дискурсом и активностью читателя, действуют в направлении той вторичности литературной семиотики /семантики, которую Тартуско-московская семиотика в свое время определила как вторичное моделирование (см. еще раз GRAMIGNA 2013). Сейчас не будем вдаваться в подробности насчет того, что в лингвистической «эстетике» Бенвениста такая не-первичная (условно назовем ее вторичной) семиотизация определяется не как «моделирование» в смысле репрезентации какой-либо действительности. Как об этом детально пишет Клоэ Лаплантин в своем представлении бенвенистовской поэтики Бодлера, художественный язык отводит от всяческого миметического моделирования (LAPLANTINE 2013: 78-79, passim). Но вопрос сейчас не в моделях. Скорее в том, как уловить интеракцию семантической активности и семиотической инвенции формы как семантико-семиотическую динамику литературного текста. Динамика в этом смысле означает просто ту активность, о которой уже много говорилось у Бенвениста, и которую следует описать как процесс, по ходу которого внетекстовая семантика-семиотика перевоплощается в художественную семантику-семиотику в результате действия системности внутриязыковых контекстов и множества в них референтных связей. Если предположим, что целостное литературное произведение на практике толкования трудно сразу разобрать как одно полное, тотальное высказывание, и поэтому необходимо сегментировать его на разные внутренние высказывания, то эти последние понимаются как внутритекстовые процессы, порождающие и порожденные различными, индивидуальными, но взаимосвязанными семантическими контекстами. Они формируют в тексте произведения целостную и многогранную системность семантического и семиотического действия. Тогда разные внутритекстовые формы «discours»' а как высказывания можно считать процессами смыслопорождения в литературном произведении, и любой процесс, по ходу которого порождается смысл, можно считать семантической единицей художественного текста, которую по типу ее семантических связей можно далее делить и сегментировать на более мелкие смысловые компоненты. Высказывание как процесс в качестве единицы смыслопорождения (процессуальное развертывание какого-то смысла) определяется тогда не длиной или типом его компонентов (будь это фонема, морфема, слово, предложение, несколько предложений), а типом и формой их внутритекстовых референтных связей (другими словами, в зависимости от того, с какими элементами и в каких формах они связываются, и на каком уровне расположена данная связь в системе семантической и семиотической иерархии высказываний и метавысказываний). Именно эти типы и формы внутритекстовых референтных связей определяют также то, какая семиотическая система создает рамку для интерпретации данных процессов. Такая смена бенвенистовской концептуализации художественного высказывания на идею толкования разных 
смыслопорождающих процессов внутри литературного текста позволяет рассматривать интеракцию и взаимосвязь семантической и семиотической динамики (процессуальную активность смыслопорождения и его семиотичность) с новой перспективы.

Так как смыслопорождение опирается на разные внутритекстовые референтные связи (включая сюда и формы разноуровневых связей с реляцией знака-метазнака всяческого типа от простых до самых сложных формаций), оказывается правомерным стремление определить соотношение знака и референта и разных знаков и референтных связей, пользуясь метафорой диалога. В этом духе связали и мы понятие динамики с диалогом, когда в начале нашей работы толковали концепцию Бенвениста в волошиновском/бахтинском контексте, к чему и обещали еще вернуться. Было выяснено, что идея «ориентации в становлении, а не в... неподвижном пребывании» (согласно установленному выше нашему терминологическому словарю: процесс смыслопорождения и его семиотичность) основывается на осмыслении понимания в качестве «ответа», при котором понимаемое обязательно вводится «в новый контекст, в возможный контекст ответа» (Волошинов/БАХтин 2000: 405). В этом свете мы указали на волошиновское/бахтинское толкование «речевого взаимодействия» в качестве ответного перевода изначального контекста в акте диалогического понимания (с «ориентацией в становлении»), и говорили о диалогических контекстуальных переводах при становлении знака и в процессе преревоплощения значения. Напомним, что становление знака и перевоплощение значения в указанном изложении бахтинского круга является, с одной стороны, «конститутивным моментом для языковой формы как для знака» (ср. «изменчивость», т. е. способность знака к трансформации); а с другой - «конститутивным моментом» «для понимания языковой формы»т. е. речь идет о неразъединенной семиотической и семантической динамике, и именно эта взаимосвязанная динамика определяется через диалогический контекст переводов контекстов как по ходу смены речевых актов (высказываний), так и по ходу смены ориентации в коммуникативной ситуации в рамках сдвига от адресанта к адресату. (В целостном контексте постановки нами проблемы в этой статье, можно подчеркнуть и сдвиг от субъекта текста к реципиенту художественного произведения.) Очевидно, что волошиновское/ бахтинское лингвистическое-семиотическое толкование таким же образом привязано к сфере теории коммуникации как и интерпретация Бенвениста.

Учитывая, что, во-первых, семантическая-семиотическая динамика понятийно так тесно может соотноситься с толкованием диалога в действительной коммуникационной ситуации, а, во-вторых, что согласно концепции Волошинова/Бахтина проблема контекстуальных переводов при перевоплощении знака и значения тесно связана с диалогом (в рамках которого возникающий ответ неотделим от понимания), действительно можно считать обоснованным терминологическое распространение понятия диалога на толкование тех связей в смыслопорождающих процессах (у Волошонива/Бахтина и Бенвениста см. высказывание/«discours»), которые мы отметили как внутри- 
текстовые референтные связи, включая сюда и соотношения разного типа знака-метазнака (текста-метатекста). ${ }^{19}$ Тем более, что у Волошинова/Бахтина «становление» однозначно предполагает процесс. А в качестве следующего шага в нашем изложении считается уместным и желательным, все еще оставаясь в рамках исследовательского наследия Бахтина и бахтинского круга ученых, выделить из концептуализации Бахтиным диалога и диалогичности те аспекты, которые теоретически можно соотнести с понятием текстовой (семантической/семиотической) динамики литературного произведения.

В первом месте напомним формулировку, подтверждающую идею о «событии слова», базисный концепт у Бахтина, и кардинальный компонент в интерпретации диалогичной природы каждого художественного слова-высказывания, от мельчайшего его воплощения до целостной текстовости литературного произведения, прежде всего романа - ср.: «диалогичность... в художественной прозе, в особенности в романе... пронизывает изнутри самое конципирование словом своего предмета и его экспрессию, преобразуя семантику и синтаксическую структуру слова. Диалогическая взаимоориентация становится здесь как бы событием самого слова, изнутри оживляющиим и драматизирующим слово во всех его моментах» (БАХТин 2012: 37). Диалог имеет семантическую функцию преображения, а динамика семантического акта преображения указывается многими прямыми и косвенными определениями и метафорами: диалог как действие словом и в слове, приводит слово к акту рождения в нем мысли, с его (слова) и ее (мысли) динамикой, состоящей в явлении трансиендентности («Тема всегда трансцендентна языку... на тему направлено... целое высказывание как речевое выступление», МЕДВЕДЕВ/БАХТИН 2000: 309). Диалог порождает семантику как «становление» - к тому же, становление касается сразу трех компонентов: 1) как участников коммуникативной ситуации диалога, субъектов-творителей нового в слове, так и 2) самого слова, в любой форме пребывающего в состоянии и реляциях диалогизированности, и 3) самих контекстов разноречия, разноязычия и разноголосицы, постоянно диалогично преломляющих слово. Тема, говорит Волошинов/Бахтин, - «сложная динамическая система знаков, пытающаяся быть адекватной данному моменту становления. Тема - реакция становящегося сознания на становление бытия» (434). Это становление в качестве творческого рождения инкорпорирует динамику, выражаемую метафорой, например, «борьбы» (акцентов [например, 366], например, в форме

${ }^{19}$ Понимание диалога в смысле «соотношения» (interrelation, cp.: «developing the concept of interrelation in terms of 'dialogism'») см., например, со ссылкой на концепцию Т. Себеока: PONZIO 2004: 39, passim. Неустарелую до сегодняшнего дня «классическую» интерпретацию многозначности бахтинского диалога см. HoLQUIST 2005. Полемику с Холквистом в вопросе диалога касательно его характера инициации и открытия см. PONZIO 2007: 188 (cp. HoLQUISTCLARK 1984). Самую свежую критическую литературу на тему разных - лингвистических и нелингвистических - толкований понятия диалога у Бахтина см. VELMEZOVA 2015; ср. осмысление «семантического» и «семиотического» и с научно-исторической перспективы в контексте творчества Н. Я. Марpa (VELmEZOVA 2013). О терминологической диалогизированности самих бахтинских понятий см. САДЕЦКИй 1997. 
«экспрессивных интонаций» и т. д., 326), но недиалогизированное абстрактное языковое значение может, например, «поглощаться» и «раздираться» темой, ее «живыми противоречиями», и так стать «смыслом», т. е. твориться как новое значение (440). О чем постоянно идет речь - это огромная онтологическая и познавательная сила трансформационной динамики творения $u$ становления субъектов-адресатов слова диалога, слова-текста разной формы и цуелостной культуры, непрестанно осмысляемой как живой континуум. Ведь указанная динамика трансформационной силы связывает настоящее культуры с ее прошлым и будущим, т. е. осмысляет ее историю. ${ }^{20}$

В дальнейшем ограничимся размышлением о проблематике литературнотекстовой динамики, как семантическо-трансформационного действия. Опираясь на эксплицитные определения и на те элементы толкования Бахтиным трансформационной динамики, которые проецируемы на проявления семантической динамики в литературном тексте, отметим лишь некоторые общие направления. Не стремясь к полному перечислению, выборочно выделим аспекты, которые затем в нашем последующем изложении будут иметь важную семиотическую релевантность.

Напомним бахтинскую трактовку диалога и диалогичности в четырех контекстах понятия семантической динамики:

1) Коничипирование словом своего предмета, где диалогичность Бахтин обнаруживает в самом предмете высказывания - она проявляется в борьбе с оговоренностью предмета. См.: «Предмет для прозаика - средоточие разноречивых голосов, среди которых должен звучать и его голос» (БАХТин 2012: 32); «И художественное изображение, resp. - образ предмета может пронизываться этой диалогической игрой словесных интенщий, встречающихся и переплетающихся в нем... Слово, пробиваясь к своему смыслу и к своей экспрессии через чужесловесную разно-акиентную среду, созвуча и диссонируя с ее различными моментами, может оформлять в этом диалогизованном процессе свой стилистический облик и тон» (БАХТин 2012: 31). В семиотической аспекте здесь открывается возможность определить бахтинское толкование литературного смыслопорождения в рамках связи разных внутренних поэтических и внешних (внелитературных и культурных) контекстов. См.: «Проблема понимания (чужого слова). Два сознания. Первое сознание (объект понимания и интерпретации) - не просто чужое индивидуальное сознание, но определенное культурное сознание, определенной эпохи, культурного сектора,

${ }^{20}$ При толковании понятия динамики в свете диалога нам хотелось бы сослаться на идею К. Эмерсон о том, что термины «диалогизм», «полифония» и «гетероглоссия» предполагают непредвиденное изменение (cp.: «not just change, but unpredictable change»). Эмерсон указывает на мысль Бахтина о новизне, которая акцентировала не автономию настоящего или будущего, а адресовала прошлому неантиципированным, продуктивным путем, и привлекала к себе подобные подходы («What Baxtin seems to have sought was newness that did not stress the autonomy of the present or the future, but that addressed the past in unanticipated, productive ways - and invited similar approaches to itself») (EMERSON 1988: 507-508). Такая проблематизация непредвиденности является тоже одним из компонентов бахтинской инспирации для Лотмана (об отношении Лотмана к Бахтину см. ЕгоРОВ 1999). 
определенной соц. группы. Встреча двух сознаний, двух времен (двух эпох); оба творчески соучаствуют и оба взаимно обогащаются» (БАХТин 2002: 402403). В итоге речь идет о действии такой динамики, которую условно назовем как культурную семантическую динамику слова. К ней принадлежит и историческая культурно-семантическая динамика (ср.: память жанров).

2) Диалог как взаимодействие между своим и чужим в русле активного взаимо-ответного понимания собеседников - отметим это явление как коммуникативно-герменевтическую семантическую динамику слова. В литературном тексте она, с одной стороны, может эксплицироваться семантической моделью диалога, с другой стороны, такая динамика касается реляции текста и реального читателя и разных семантических моделей данного отношения (ср.: текст и читатель; модели коммуникации в тексте и т. д.). См.: «Этот новый вид внутренней диалогичности слова отличается от того, который определялся встречею с чужим словом в самом предмете: здесь не предмет служит ареною встречи, а субъективный кругозор слушателя» (БАХТин 2012: 36).

3) Романный язык как система - имеется в виду упорядочение разноязычия, разноречия и разноголосиц, воплощенных в разных нарративных, персонажных, хронотопных, мотивных, интертекстуальных образованиях, которые интегрируются в семантическую систему. Эта организующая сила движет системной динамикой литературного текста. См.: «Эти особые связи и соотношения между высказываниями и языками, это движение темы по языкам и речам, ее дробление в струях и каплях социального разноречия, диалогизация ее - такова основная особенность романной стилистики, спецификум ее» (БАХТин 2012: 15-16); «И эта фактическая расслоенность и разноречивость не только - статика языковой жизни, но и динамика ее: расслоение и разноречивость ширятся и углубляются, пока язык жив и развивается; рядом с силами центростремительными идет непрерывная работа центробежных сил языка, рядом со словесно-идеологической централизацией и объединением непрерывно идут процессы децентрализации и разъединения» (БАХТИн 2012: 25). В конечном счете здесь намечается семантическая динамика системной интеграции.

4) Семантическая динамика дистанцирования воплощает направленность слова вне себя - сюда принадлежат модели изображенного слова, разные метатекстовые проявления. В случае системного выстраивания метатекстов по отношению к тексту и языку, которые осознаются в литературном произведении или в определенных его частях и внутренних контекстах как «собственные», может создаваться целостный авторефлексивный слой романа. ${ }^{21}$

${ }^{21}$ И Ю. Кристева пользуется термином дистаницирование, интерпретируя аспекты диалогической логики. Среди них фигурирует одновременно логика дистанциирования и логика отношений «между различными членами предложения или нарративной структуры, что предполагает становление - в противоположность уровню континуальности и субстанциальности, которые подчиняются логике „бытия“ и могут быть обозначены как монологические» (КРИСтеВА 2001: 223). Дистанциирование в указанной работе определяется в отличающейся от нашей системе аспектов (о других аспектах см. далее КРистЕВА 2001). 
На основе указанных форм функционализации диалога в русле создания семантической динамики литературного текста, четыре типа процессов динамизации стоит различать и по той характеристике, что 1) культурная семантическая динамика и 2) коммуникативно-герменевтическая семантическая динамика слова подразумевают установку на семантизацию, в то время как 3) семантическая динамика системной интеграции и 4) семантическая динамика дистанцирования более акцентированно включают в себя толкование семантических операций, которые более однозначно подводят нас к проблеме семиотизации. А если учитывать семиотические аспекты динамики смыслопорождения, причисленного к определенным выше категориям, то следует особенно отметить следующие черты, включенные в разные случаи концептуализации Бахтиным семантической активности (в качестве первой постановки вопроса ср. ИвАнов 1973):

- В литературном тексте действуют разнообразные знаки, принадлежащие к разным знаковым системам.

- В процессе смыслопорождения связываются знаки и знаковые системы (реляционное смыслопорождение).

- Внетекстовые нелитературные и литературные системы вовлекаются во внутритекстовую систему.

- Литературный текст через свою семиотическую систему участвует в разных формах культурной коммуникации:

а) становится представителем культурной коммуникации в слове, в жанре и т. д.;

б) сам моделирует разные формы культурной коммуникации (например, модели писания-чтения, интертекстуальность и т. п.);

в) участвует в автокоммуникации (дистанцирование от языков: разные метатексты, дешифровка - процесс постоянного превращения знака в референт) и в итоге литературный текст систематически толкует сам себя в разных формах семантизации своей авторефлексивности.

- Семантическая связность, когерентность литературного текста основывается на указанном процессе создания-толкования смысла (логику такой связности можно определить по разным осям: текст-метатекст; знак-референт; анафорическое и катафорическое семантическое упорядочение; семантическая интеграция и дизъюнктивность).

Напомним, что указанные семиотические свойства литературного текста были выведены нами на основе определения четырех аспектов семантической динамики, включая туда и операции объединения и разъединения. Как раз действие проявлений указанных компонентов динамики и семиотизируют литературный текст как семиотическую систему. Размышляя о связи семантической и семиотической динамики, на этой основе можно определить, что уловимые аспекты семантической динамики делают ощутимой семиотическую натуру литературного произведения. Позже, с целью нюансирования данной мысли, будем размышлять еще и в противоположном направлении, в надежде выяснить функцию семиотизащии в дальнейших процессах 
семантизации в художественном тексте. Взаимосвязь семантической и семиотической динамики литературного текста видимо также имеет свою общую динамику. Семантическая динамика создает разные виды системности, на разных уровнях текстопостроения (благодаря этой динамике создаются внутри- и внетекстовые, точнее: внутри- и внекультурные виды системности, которые соприкасаются друг с другом). Семантические ходы, следовательно, порождают семиотическую организацию, в результате чего читатель способен нащупать разные знаковые системы и подсистемы в тексте, а затем процессы семантизации-семиотизации осознаются в качестве «диалога» шире: смысловой реляционности (соотнесенности) самих знаковых систем. Но при сцеплении знаковых систем, т. е. семиотического «диалога» обновляется динамика литературного смыслопорождения в духе специфики той семантической динамизирующей силы, которую Бахтин присваивает любому диалогу словом. Семиотизированность литературного текста, в рецептивном процессе возникающая в результате семантизированности этого же текста (в результате реляционных смыслов его подсистем и их частей), приводит по ходу активного восприятия и понимания вербального художественного произведения уже к учету интерсемиотических диалогов. А интерсемиотические диалоги означают семиотические переводы и делают осознанным текст не только как полифонически многодискурсивную, но и как семантически иерархизированную систему. Иерархизированная многоярусность построения текста действует в русле семантической динамики текста. Однако обеспечивается она именно динамикой интерсемиотических диалогов, которые осуществляются в форме переводов смысла с одного уровня текста на другой, из одной семиотической системы в другую, но указывая на то, что диалог как реляционная активность, как динамическое соотношение является лишь частью более комплексной системы, о которой ни в коем случае нельзя сказать, что она двухсоставная или дихотомически бинарная. Чередование семантической и семиотической динамики текста в порождении поэтики художественного произведения выдает такое же двуголосие, развернутое в дискурсивном процессе, как те другие формы диалога, которые анализирует Бахтин применимо к литературному тексту. Чередование семантической и семиотической динамики поэтики литературного текста появляется как формирующая сила художественного дискурса.

Вопрос дискурсивизации диалога семантической и семиотической динамики текста в тех главных, можно сказать, уже классических, а также и в новых критических работах, которые поставили своей задачей интерпретировать бахтинское наследие для общей и культурной семиотики, не ставится как индивидуальная проблема.

Ю. Кристева в своей знаменитой статье (написанной в 1967 г.), исходя из концепции диалога Волошинова/Бахтина и по сути дела понимая разные формы слова и высказывания как знак и текст, перевоплощает толкование соотношения знаков в теорию интертекстуальности. Она тоже опирается на толкование слова как «семического комплекса» (КРистЕВА 2001: 215), которое 
сочленяется с другими словами на разных уровнях по величине синтагматических единиц. Указываются три измерения «текстового пространства, в котором происходит оперирование разными семическими комплексами и поэтическими синтагмами», - ср.: субъект письма, получатель и внеположные им тексты, т. е. «три инстанции, пребывающие в диалоге» (КРИСтевА 2001: $215)$, - которые затем интерпретируются в следующих направлениях соотношений: 1) субъекта-получателя [горизонтальная ось - К. К.], 2) текстаконтекста [вертикальная ось - К. К.]. В чтении Кристевой они одинаково сводятся к текстовым отношениям (получатель тоже определяется как дискурс). И с этой точки зрения можно интерпретировать утверждение, что «всякое слово есть пересечение других текстов» (КристевА 2001: 215). Хотя Кристева в творчестве Бахтина больше всего оценивает то, что он одним из первых «взамен статического членения текстов предложил такую модель, в которой литературная структура не наличествует, но вырабатывается по отношению к другой структуре» (это явление и называет она «динамизацией структурализма»), и указывает на толкование Бахтиным «слова» как «места пересечения текстовых плоскостей» (КРистеВА 2001: 213-214), она еще меньше Бахтина уточняет эти текстовые плоскости, называя все типы пересечения интертекстуальными. В рамках данной интерпретации остаются без выделения формы привлечения к какому-то тексту неодинаковых других текстов и знаковых парадигм (семиотических систем) и действие пересечения отличающихся друг от друга внутритекстовых формаций в литературном произведении. В данном изложении единственный аспект постановки проблемы перевода представляется как «перевод любого литературного (языкового) сегмента в горизонтальное измерение и установление там его коррелятивных связей» (КристевА 2001: 220). Этот перевод связан с поставленным нами вопросом дискурсивизации. Кристева говорит о процессах, когда устанавливает, что «статус слова как минимальной единицы текста является не только медиатором, связывающим структурную модель с ее культурным (историческим) окружением, но и регулятором, управляющим процессом перехода диахронии в синхронию (в литературную структуру)» [курсив в оригинале - К.К.] (КристеВА 2001: 215-216). С другой стороны, Кристева акцентирует возможность анализа диалогического взаимодействия двух языковых осей, синтагматической и той, которую мы могли бы назвать парадигматически-систематической языковой осью. В их связи она видит «основу романной амбивалентности» (КРистеВА 2001: 218). Вяч. Вс. Иванов, выстраивающий в своем толковании многогранную систему интерпретации семиотических черт в концепции Бахтина, в вопросе перевода ссылается на бахтинскую идею «перемещения слова из одного ценностного контекста в другой» (ИвАнов 2001: 267). При выяснении повтора знака в литературном тексте ученый задается вопросами, связанными с синтаксисом смыслопорождения в контексте «модели для непрерывного случая» семантизациии или дискретности ее этапов. По сути дела такой подход близок к подходу Кристевой, испытывающему логику соотношения синтагматической и парадигматической 
семантизации. Тем не менее проблема перевода в толковании Ивановым Бахтина совсем не акцентирована и не затрагивается и в интерпретации соотношения знаковых систем (ИвАнов 2001: 291, passim) и метаязыка (ИвАнов 2001: 292).

Как у Бахтина, так и в работах ученых, интерпретирующих его творчество в свете семиотики (см. также, например, PonZIO 1998), в основном отсутствует теоретическое обоснование проблемы дискурсивизации в литературном прочзведении чередования семантической и семиотической динамики текста. Для осознания этой дискурсивизации нельзя обойтись без толкования функции интерсемиотического перевода, о котором Пеэтер Тороп многосторонне пишет как относительно целостных культурных пространств (TOROP 2002), так и внутритекстовых литературных пространств (например, Тороп 1995). Ю. М. Лотман в своей работе «Наследие Бахтина и актуальные проблемы семиотики» (1984) интерпретирует бахтинскую концептуализацию диалогичности именно в контексте динамичности знака, который (помимо прочего, см.: высказывание и любой новый текст) через целостные знаковые системы в культурном пространстве всегда готов вступить в диалог, чем и увеличиваются культурные коммуникативные каналы. Лотман все это многократно связывает и с проблемой перевода и в духе Бахтина предполагает, что по ходу обновления культурно-коммуникативного канала обновляется и семантика (мы можем утверждать, что вычеркивается именно та себетождественность, о которой говорит Волошинов/Бахтин в связи с сигнализацией, когда налицо лишь языковое значение вместо творческого смысла), - два текста, созданных в двух коммуникативных системах, никогда не тождественны. Подчеркивая, что при параллельности культурно-коммуникативных систем и каналов имеются отличия, Лотман проецирует одну систему на другую, при этом и предполагается между ними соотношение, т. е. смысл, выводимый из соотношений систем (реляционное значение). А связь этих систем как действие семиотических стратегий культуры, принадлежащих к творческому сознанию, заложенному в порождении новых текстов, интерпретируется Лотманом в свете процессов семантизации, которую он толкует в контексте «унифицированной» и «деунифицированной» «семиотической ситуации» (первая гарантирует информационный обмен, а вторая - «гарантирует и возможность создания нового текста, и передачу новой информации»). В их констелляции появляется возможность передавать новую культурную информацию [наличие механизма однозначного информационного обмена нужно для того, чтобы «новые тексты» в качестве обновления семиотизации и, следовательно, семантизации, могли функционировать - К. К.]. Данная ситуация, таким образом, способствует также увеличению семиотического пространства культуры. Семантика (новая информация) и семиотика (новые семиотические коммуникативные каналы и принадлежащие к ним тексты) по ходу действия культуры идут рука об руку. В русле выяснения указанной взаимосвязи в рассматриваемой статье эксплицируется Лотманом один важный аспект диалога как «динамического знака», в духе Бахтина (ЛотмАн 2002). 
Толкование Лотманом концепции бахтинского диалога в контексте полилога, почти тезисно формулируется примерно на десятилетие раньше в «Анализе поэтического текста»: «...принцип монологизма вступает в противоречие с постоянным перемещением семантических единиц в общем поле построения значений. В тексте все время идет полилог различных систем, сталкиваются разные способы объяснения и систематизации мира, разные картины мира. Поэтический (художественный) текст в принципе полифоничен» (ЛотмАн 1972: 110). ${ }^{22}$

Перемещение семантических единиц неразрывно связано с обновлением их семиотизации. ${ }^{23}$ Вопрос тогда заключается в том, как сами процессы семантизации и семиотизации вступают в «диалог», и остаются ли разные «диалогические» соотношения в качестве составной части целостной текстовой системы равноправными, или же их толкование требует от интерпретатора раскрытия модели иерархизованного чередования семантической и семиотической динамики литературного текста.

\section{Приложение}

\section{Аспект «диалога» семантической и семиотической динамики в «Герое нашего времени»}

В «Герое нашего времени» рамочным семантическим контекстом для толкования модели диалога служит Предисловие как эксплицитное обращение к читателю. Перед нами как бы настоящий автор романа. Он в результате опыта, приобретенного от читательской реакции предыдущего издания книги, на этот раз дает советы реципиенту своего произведения, указывая на то, как следует воспринимать его содержание. Многосторонняя система эквивалентностей, тем не менее, превращает биографического автора в фиктивный персонаж, а предисловие, содержащее в себе стратегии чтения, - в неотъемлемую часть романа, который начинается с парадоксального сочетания мотивов начала и конща: «Во всякой книге предисловие есть первая и вместе с тем последняя вещь» (ЛЕрмонтов 2000: 212).

Разные тематические и мотивные сходства явно связывают эту первую и в то же время последнюю часть романа (по сути дела его начало и конец)

${ }^{22}$ См. также: «Текст не дает конечной интерпретации и - он лишь указывает границы рисуемой им картины мира. Таким образом, анализ этого стихотворения позволяет нам проследить механизм полифонического построения текста (термин М. М. Бахтина). Значение дается не словами или сегментами текста, а отношением между точками зрения» (ЛотмАН 1996: 177). О толковании смысла незаконченности в противоположность идее релятивности см. EMERSON 1988: 508-509 и далее.

${ }^{23}$ Тамба-Мец при толковании концепции Бенвениста в противоположность семантизации языка («sémantisation de la langage») формулирует мнение, что действительное обнаружение Бенвениста - это семиотизация дискурса («la sémiotisation du discursif») (ТАмБА-МЕЦ 1984: 196). 
с тремя другими текстовыми местами: с последней главой «Героя нашего времени», с «Фаталистом», и там особенно с концом, где поставлена тема чтения предопределенного конца человеческой судьбы по написанным знакам, чем и явно сополагаются темы конца жизни и конца текста. Третье место, приведенное в ряд эквиваленций - Журнал Печорина, который прерывается после 16-го июня, в день дуэли Печорина. Когда герой опять берется за перо, он сначала перечитывает «последнюю страницу» уже написанной части дневника. Эта последняя страница содержала в себе мысли о грозящей Печорину смерти на дуэли, о конце его жизни. Текст жизни и текст $о$ жизни (метатекст) опять соотносятся семантически. Продолжение журнала обращает на себя внимание тем, что оно следует после того, как окончив дуэль, герои завершают и определенную форму драматизации жизненных текстов. В этом духе смерть Грушницкого создает состояние «Finita la comedia» (см. ЛЕРмонтов 2000: 348). Но только что завершена та ролевая игра, которая создала трагикомическую сцену дуэли, старый текст сразу же меняется новым: Печорин получает письмо от Веры. Это письмо он читает, а потом так как «каждое слово неизгладимо врезалось» в его памяти, он вписывает строки Веры в свой журнал. Семантическая мотивировка письма Веры свидетельствует о том, что доверие Веры к Печорину, основывается на том, что Печорин много раз уверял ее в его верности к ней. Итак, перед нами последовательный ряд повтора коммуникативной-герменевтической ситуации: реципиент слова (устного или письменного) читает текст другого и интерпретирует его в следующем тексте. Вера верит в слова Печорина, о чем свидетельствует ее письмо, которое Печорин читает, а потом переписывает его в свой Журнал, который, со своей стороны, становится частью романа. Но этот журнал прекращается там, где еще не finita la comedia, еще нужно ее завершить, а потом закончить, т. е. продолжить, т. е. нужно заново начать писать также и журнал. И так далее и тому подобное.

Перед глазами вырисовывается сюжет систематического воссоздания коммуникативно-герменевтической ситуации, когда отправитель и получатель текстов только что выходят из одного текста, уже интерпретируют его метатекст, а по ходу этого процесса релятивизируется смысл начала и конца, точнее старый конец становится новым началом, последний этап которого воплощается в Предисловии романа, странно соединяющем начало и конец.

Почему интересен этот ряд, это как бы нагромождение модели писания и чтения? По той поэтической причине, что он составляет семантический сюжет. И по той семиотической причине, что метатекст всегда создает новую семиотическую микросистему, новый текст, что и приводит к тому, что семиотические перевоплощения (по сути дела переводы) функционируют как интерсемиотические переводы в романе Лермонтова. Они не просто повторяют герменевтическую диалогическую ситуацию. Они движут сюжет вперед, на двух уровнях семантизации. Все новые и новые тексты вновь и вновь говорят о проблеме завершения, окончания, конца (относительно человеческой жизни семантизируется дилемма смерти). А на уровне же авто- 
рефлексивности романа, во всех новых текстовых и семиотических воплощениях мы узнаем больше и больше о том, как рождается лермонтовский роман из ряда повторов все нового и нового отношения текстов и метатекстов. Процессы семиотизации и интерсемиотические диалоги, возникающие в их результате, порождают семантику. Это и есть вторая сторона свойства связи семантической и семиотической динамики литературного текста. Семантическая динамика семиотизируется. А затем семиотическая динамика превращается в форму семантизации. Диалог полон. Речь идет не о форме и содержании. Но и не о сигнале и о «чистом» знаке. Узнавание как форма семантизации и как форма семиотизации становится закономерной частью понимания той взаимной семантической и семиотической динамики литературного текста, в диалоге которых с их широкими культурными и герменевтическими контекстами порождается поэтический смысловой мир литературного произведения. Все это говорит о том, что мы не можем провести такое разграничение между семантическими и семиотическими исследованиями, которое дало бы возможность исключить толкование «семиотической» ${ }^{24}$ природы художественной семантизации в литературном тексте.

\section{Литература}

АлПАтов 2005 = АлПАТов В. М. Волошинов, Бахтин и лингвистика. Москва: «Языки славянских культур», 2005.

БАХТИН 2002 = БАХТИН М. М. Собрание сочинений в 7 томах. Т. 6. Проблемы поэтики Достоевского 1963. Работы 1960-х - 1970-х г2. Москва: «Русские словари», «Языки славянских культур», 2002.

БАХТин 2012 = БАХтин М. М. Собрание сочинений в 7 томах. Т. 3. Теория романа 1930-1961 гг. Москва: «Языки славянских культур», 2012.

БЕнВенист 1974 = БЕнВенист Э. Семиология знака. В кн.: БЕнВениСт Э. Общзая лингвистика. Москва: «Прогресс», 1974. 69-89.

Волошинов/БАХтин 2000 = Волошинов В. Н. Марксизм и философия языка. Основные проблемы социологического метода в науке о языке. В кн.: Бахтин под маской. Москва: «Лабиринт», 2000. 349-486. [Ленинград: «Прибой», 1929.]

ГрЖиБЕК 1995 = ГРЖиБЕк Петер: Бахтинская семиотика и московско-тартуская школа. В кн.: Пермяков Е. В. (ред.) Лотмановский сборник. Т. 1. Москва: «Иц-Гарант», 1995. 240-259.

ЕГоров $1999=$ Егоров Б. Ф. Бахтин и Лотман. В кн.: Жизнь и творчество Ю. М. Лотмана. Москва: «Новое литературное обозрение», 1999. 243-258.

ИвАнов 2001 = ИвАнов Вяч. Вс. Значение идей М. Бахтина о знаке, высказывании и диалоге для современной семиотики. В кн.: М. M. Бахтин. Pro et contra. Т. 1. Санкт-Петербург: «Издательство Русского христианского гуманитарного института», 2001. 266-311. [Труды по знаковым системам VI. Ученые записки Тартуского университета 308. Tartu, 1973. 5-44].

${ }^{24}$ См. о том, что согласно теории Бенвениста сам текст должен быть исследован через семантику (IVANOV 1999: 3). 
КриСТЕВА 2001 = КриСТЕВА Ю. Бахтин, слово, диалог и роман. В кн.: М. М. Бахтин. Pro et contra. T. 1. Санкт-Петербург: «Издательство Русского христианского гуманитарного института», 2001. 213-243.

ЛЕРмонтов $2000=$ ЛЕРмонтов М. Ю. Герой нашего времени. В кн.: ЛЕРмонтов М. Ю. Полное собрание сочинений в 10 томах. Т. 6. Проза. Москва: «Воскресенье», 2000. 212-366.

Лотман 1972 = Лотман Ю. М. Анализ поэтического текста. Ленинград: «Просвещение», 1972.

ЛотмАН 1996 = ЛотмАН Ю. М. «Два голоса» Ф. И. Тютчева. Анализ поэтического текста. Структура стиха. В кн.: ЛотмАн Ю. М. О поэтах и поэзии. Санкт-Петербург: «Искусство-СПб», 1996. 173-177.

ЛотмАН 2002 = ЛотмАН Ю. М. Наследие Бахтина и актуальные проблемы семиотики. В кн.: ЛотмАн Ю. М. История и типология русской культуры. Санкт-Петербург: «Искусство», 2002. 147-156.

ЛОТМАН-УСПЕНСКИЙ $2000=$ ЛОТМАН Ю. М., УСПЕНСКИЙ Б. А. Условность в искУсстве. В кн.: ЛотмАн Ю. М. Об искусстве. Санкт-Петербург: «Искусство», 2000. 374-377.

МЕДВЕДЕВ/БАХТИН $2000=$ МЕДВЕДЕВ П. Н. Формальный метод в литературоведении. Критическое введение в социологическую поэтику. В кн.: Бахтин под маской. Москва: «Лабиринт», 2000. 195-348. [Ленинград: «Прибой», 1928.]

Пятигорский 1962 = Пятигорский А. М. Некоторые общие замечания относительно рассмотрения текста как разновидности сигнала. В кн.: МолошнАя Т. Н. (ред.) Структурно-типологические исследования. Москва: «Издательство Академии наук СССР», 1962. 144-154.

САДЕЦКИЙ 1997 = САДЕЦКИЙ А. ДиаЛогическое становление. Слово Бахтина в оригинале и в переводе: проблемы дискурсивной аксиологии. В кн.: ТАмАРчЕнко Н. Д. Бахтинский тезаурус. Материаль и исследования. Москва: «Издательство Российского государственного гуманитарного университета», 1997. 17-132.

СТЕПАНОВ 1974 = СТЕПАНОВ Ю. С. Комментарий. В кН.: БЕНВЕНИСТ Э. Общая лингвистика. Москва: «Прогресс», 1974. 407-445.

ТоРоп 1995 = ТоРоП П. Тотальный перевод. Тарту: «Издательство Тартуского университета», 1995.

ФАРЫно 1988 = ФАРыно Е. Паронимы - анаграмма - палиндром. Wiener Slawisticher Almanach 21. Wien, 1988. 37-54.

ФАРЫно 1989 = FARYNO J. Дешифровка. Russian Literature 26 (1989): 1-67.

ADAM 2011 = ADAM J.-M. Le programme de la « translinguistique » des textes, des oeuvres et sa réception au seuil des années 1970. In: BRUNET-MAHRER 2011. 123-147.

ARESI 2011 = ARESI F. Bakhtin e Benveniste: convergências e divergências na elaboração de uma feflexão enunciativa / Bakhtin and Benveniste: convergencies and divergencies in the elaboration of an enunciative reflection. Revista UNIABEU 2011/4: 43-55.

Benveniste 1966 = Benveniste E. Problèmes de linguistique générale 1 [PLG1]. Paris: Gallimard, 1966.

Benveniste 1969 = Benveniste E. Sémiologie de la langue. Semiotica 1 (1969): 127-135.

Benveniste 1974 = Benveniste E. Problèmes de linguistique générale 2 [PLG2]. Paris, Gallimard, 1974.

Benveniste $1981=$ Benveniste E. The semiology of language. Semiotica (Special Supplement) 1 (1981): 5-23. 
Brunet-Mahrer 2011 = Brunet É., Mahrer R. Relire Benveniste. Réceptions Actuelles des Problèmes de linguistique générale. (Sciences du langage. Carrefours et points de vue 3.) Paris: L'Harmattan-Academia, 2011.

EMERSON 1988 = EMERSON C. Problems with Baxtin's Poetics. The Slavic and East European Journal 32 (1988): 503-525.

GrAmignA 2013 = GrAmignA R. The place of language among sign systems. Juri Lotman and Emile Benveniste. Sign Systems Studies 41 (2013): 339-354.

Guigue 2011 = Guigue V. Incidence de l'opposition langue-discours chez É. Benveniste pour une réévaluation du concept du discours en analyse du discours. In: BRUNETMAHRER 2011. 149-168.

Holquist 2005 = Holquist M. Dialogism. Bakhtin and his World. 2nd edition. LondonNew York: Routledge, 2005.

Holquist-Clark 1984 = Holquist M., Clark K. Mikhail Bakhtin. Cambridge, Mass.: Belknap Press, 1984.

IVANOV 1999 = IVANOV Vyacheslav: Bakhtin's Theory of Language from the Standpoint of Modern Linguistics. http://www.indiana.edu/ slavconf/baxtin/positpapers/ivanov.pdf. [Material from the Bakhtin Workshop "Bakhtin in Context(s)", 3-5 December 1999, Department of Slavic Languages and Literatures at Indiana University, Bloomington.]

LAPLANTINE 2011 = LAPLANTINE C. La poétique d'Émile Benveniste. In: BRUNET-MAHRER 2011. 71-95.

MeschonNiC 1997 = MeschonNIC H. Benveniste: sémantique sans sémiotique. Linx 9. Paris, 1997. 307-326. http://linx.revues.org/1075.

PonzIO 1998 = PonzIO A. Bakhtin's Semiotics as Philosophy of Language. Semiotische Berichte 1998/3-4: 19-33.

Ponzio 2004 = PonzIO A. Biologism and biosemiotics. Semiotica 150. Berlin, 2004. 39-60.

PonZIO 2007 = PonZIO A. Dialogue, intertextualité et intercorporéité dans l'oeuvre de Bakhtine et du Cercle. In: Vauthier B. (ed.) Bakhtine, Volochinov et Medvedev dans les contextes européen et russe. Slavica Occitania 25. Toulouse, 2007. 181-202.

TAMBA-MECZ 1984 = TAMBA-MECz I. A propos de la distinction entre "semiotique » et « semantique» chez E. Benveniste. In: SERBAt Guy (éd.): E. Benveniste aujourd'hui. Actes de Colloque international de C.N.R.S. Univeristé François Rabelais. Tours, 28 30 septembre 1983. T. 1. Paris: Éditions Peeters, 1984. 187-198.

Torop $2002=$ Torop P. Translation as Translating as Culture. Sign Systems Studies 30 (2002): 593-604.

Velmezova 2011 = Velmezova E. From semantics to semiotics. A page of early Soviet intellectual history. Sign Systems Studies 39 (2011): 224-235.

Velmezova 2015 = Velmezova E. The Bakhtinian Dialogue Revisited: A (Non-biosemiotic) View from Historiography and Epistemology of Humanities. In: Velmezova E., Kull K., Cowley S. J. (ed.) Biosemiotic Perspectives on Language and Linguistics. (Biosemiotics 13.) Cham: Springer, 2015. 275-290. 